\title{
Tekrarlayan Akut Bronşiolit Tanılı Hastaların Retrospektif Değerlendirilmesi
}

\author{
Retrospective Evaluation of Patients with Recurrent Acute Bronchiolitis
}

\section{Sema ATEŞ ${ }^{1}$, Necati EMRECAN ${ }^{2}$}

1. Ankara Çocuk Sağllğı ve Hastalıkları Hematoloji Onkoloji Ĕ̆itim ve Araştırma Hastanesi, Çocuk Sağlı̆̆ı ve Hastalıkları Anabilim Dalı, Ankara, Türkiye

2. Ankara Çocuk Sağlığı ve Hastalıkları Hematoloji Onkoloji Ĕgitim ve Araştırma Hastanesi, Çocuk Sağlı̆̆ı ve Hastalıkları Anabilim Dall, Ankara, Türkiye

\section{$\ddot{O Z Z E T}$}

Amaç: Akut bronșiolit, özellikle iki yaș altı çocuklarda, küçük hava yollarinin enflamatuvar obstrüksiyonu sonucu ortaya çıan alt solunum yollarının en sık görülen hastalığıdır. Bazı predispozan faktörler ve altta yatan hastalıklar bronşiolit de tekrarlayan ataklara neden olabilir. Calısmamızda Tekrarlayan Bronşiolit tanılı infantların geriye dönük olarak değerlendirilmesi amaçlanmıştır.

Gereçler ve Yöntem: 1 Ocak 2016-31 Aralı 2017 tarihleri arasında hastanemiz süt çocuğu servisinde yatarak takip edilen, yaşları 1-24 ay arasında değişen Akut bronşiolit tanıl 759 hastanın dosyalarl iki yıllık geriye dönük olarak tarandl. Bu hastalardan birden fazla atak geçiren 231 olgu çalışmaya alındl. Hastaların yaşı, cinsiyeti, geçirdiği atak sayısı, ilk atak yaşı ve hastalığın görüldüğü mevsim gibi demografik özellikleri incelendi. Etyolojiye yönelik yapılan Ekokardiyografi, ve solunum yolu viral paneli tetkiki sonuçları, tekrarlayan ataklarda altta yatan hastalik, prematüre doğum, hasta ve ailede atopi öyküsü kaydedildi.

Bulgular: 1 Ocak 2016-31 Aralık 2017 tarihleri arasında yatarak takip edilen Tekrarlayan Bronşiolit tanılı 231 hasta çalışmaya alindr. Hastaların yas grupları incelendiğinde en kalabalık grubu 1-6 ay arası hastalar oluşturmaktaydı. Hastaların çoğunun $(\% 70,6)$ ilkbahar ve kış mevsiminde hastaneye bașvurduğu görüldü. Etyolojiye yönelik tetkikler sonrası atakların tekrarlamasına zemin hazırladığ dü̈sünülen hastalıklar; viral bronsiolit, gastro özefagial reflü, konjenital kalp hastalıkları, kistik fibrozis, wheezing infant olarak saptandl. Solunum Yolu Viral Paneli sonuçlarına göre viral bronșiolit 'in en sik respiratuar sinsinyal virüs, parainfluenza ve rhinovirus kaynakl olduğu görüldü.

Sonuç: Akut bronşiolit de atakların tekrarlamasına zemin hazirlayan faktörlerin bilinmesi, erken teshis ve tedavi ile hastaneye yatış oranını azaltacaktır.

Anahtar Kelimeler: tekrarlayan bronşiolit, infant, etyoloji

\section{ABSTRACT}

Objective: Acute bronchiolitis is the most common disease of lower respiratory tract caused by inflammatory obstruction of small airways, especially in children under two years of age. Some predisposing factors and underlying diseases can cause recurrent attacks in bronchiolitis. The aim of this study was to evaluate the recurrent bronchiolitis-diagnosed infants retrospectively.

\section{İletișim}

Sorumlu Yazar: Uzm. Dr Sema ATEŞ

Adres: Ankara Çocuk Sağlığı ve Hastalıkları Hematoloji Onkoloji Eğt. ve Arş. Hast., Çocuk Sağ. ve Hastalıkları Ana B. Dalı, Ankara, Türkiye Tel: +90 (507) 6134188

E-Posta: drcici86@hotmail.com

Makale Geliș: 27.09.2018

Makale Kabul: 26.11.2018

DOI: http://dx.doi.org/10.16948/zktipb.464411
Material and Methods: The files of 759 patients with acute bronchiolitis aged between 1-24 months, who were followed-up in the infant-care unit of our hospital between January 1, 2016 and December 31, 2017, were reviewed retrospectively for two years. 231 patients with multiple episodes were included in the study. Demographic characteristics of patients such as age, gender, number of attacks, first episode age were examined. Echocardiography, findings of respiratory tract viral panel examinations, history of recurrent episodes, premature birth, history of atopy in the patient and family were recorded.

Results: A total of 231 patients with recurrent bronchiolitis who were hospitalized between January 1, 2016 and December 31, 2017 were included in the study. When the age groups of the patients were examined, the most crowded group consisted of 1-6ay patients. Most of the patients (70.6\%) were admitted to hospital in spring and winter. Diseases thought to prepare the ground for recurrence of attacks; viral bronchiolitis, gastro esophageal reflux, congenital heart disease, cystic fibrosis, wheezing infant. According to the results of the respiratory tract viral panel, viral bronchiolitis was the most common cause of respiratory syncytial virus, parainfluenza and rhinovirus.

Conclusion: Knowing the factors that cause the recurrence of attacks in acute bronchiolitis will reduce the rate of hospitalization by early diagnosis and treatment.

Keywords: recurrent bronchiolitis, infant, etyology

\section{GíRiş}

Akut bronșiolit iki yaşından küçük çocuklarda sıklıkla viral etkenlerin neden olduğu, hızlı nefes alıp verme, göğüste retraksiyonlar ve hışıltılı solunum (wheezing) ile karakterize, bronşiollerin inflamasyonu ile seyreden klinik bir hastalıktır (1, 2). Çoğunlukla 2 yaşından daha küçük çocuklarda, en sik 1-6 ay arasında görülür (3). Özellikle kıș aylarında epidemiler halinde görülür. Sosyoekonomik düzeyi düşük olan ailelerde, kalabalık ortamda yaşayan, sigara dumanına maruz kalan ve anne sütü almayan bebeklerde daha siktır.

Akut bronşiolit nedeniyle hastaneye yatırılan 2 yaşın altındaki çocuklarda en sık (\%75) respiratuvar sinsityal virüs (RSV) izole edilmektedir. RSV tüm bronșiolitli olguların \% 20-40'ında, 2 yaşından küçük çocukların \% 44'ünde, yaşamın ilk yılında ise $\% 80$ 'den fazlasının etkenidir (4). Akut bronşiolit tüm yaş gruplarını etkilemekle birlikte bir yaşın altındaki çocuklarda daha șiddetli seyretmektedir. 6 haftadan küçük bebeklerde ve altta bir hastalık olduğu durumlarda daha ağır geçer ve hastaneye yatış gerekir (5). Tanı yaş, mevsimsel oluş ve fizik muayene bulgularına dayanır.

Akut bronşiolit sonrası tekrarlayan hışı1tı atakları görülebilir. Bu ataklar, akut bronşiolit' in immün 
yanıtı değiştirerek astım ortaya çıkmasını kolaylaştırması ya da zaten astımı var olan çocukların tekrarlayan akut bronşiolit atakları geçirmeleri sonucu ortaya çıkabilir. Çocukta ve ailede atopi ve alerji öyküsü, çocuğun solunum yollarının doğuștan dar olması ve pasif sigara içiciliği, gastro özefagial reflü (GÖR), konjenital kalp hastalığı tekrarlayan h1ş1ltı atakları gelişmesi için risk faktörleridir. Bu tür hastalar astım yönünden de değerlendirilmelidir (6, 7) $\mathrm{Bu}$ çalışmada, kliniğimizde yatarak takip edilen tekrarlayan bronşiolit tanılı olguların demografik özellikleri, etyolojiye yönelik tetkikler ve altta yatan hastalıklar analiz edildi.

\section{GEREÇ ve YÖNTEM}

Bu çalışmada Ankara Çocuk Sağlığı ve Hastalıkları Hematoloji Onkoloji Eğitim ve Araştırma Hastanesi Süt Çocuğu Servisinde 1 Ocak 2016-31 Aralık 2017 tarihleri arasında yatarak takip edilen yaşları 1-24 ay arası değişen, Akut Bronşiolit tanılı 759 hastanın dosyaları iki yıllık geriye dönük olarak tarand1. Bu hastalardan birden fazla atak geçiren 231 olgu çalışmaya alındı.

Hastaların yaşı, cinsiyeti, geçirdiği atak sayısı, ilk atak yaşı ve hastalığın görüldüğü mevsim gibi demografik özellikleri; etyolojiye yönelik yapılan Ekokardiyografi, ve solunum yolu viral paneli tetkiki sonuçları, tekrarlayan ataklarda altta yatan hastalık, prematüre doğum, hasta ve ailede atopi öyküsü kaydedildi. Hastada atopik dermatit, egzema bulunmasi ve birinci derece akrabalarda astım, egzema veya alerjik rinit bulunması atopi öyküsü mevcut olarak kabul edildi. Doğum haftas $<<=37$ hafta olanlar prematüre olarak değerlendirildi. Kronik hastalığg mevcut olan hastalar bronşiolit atağ1nın tekrarlamasına etki edebileceği için çalışmaya alınmadı, hastanın yatışı süresince yapılan tetkiklerle saptanan ve tekrarlayan bronşiolit 'e neden olduğu düşünülen hastalıklar verilere kaydedildi.

\section{İSTATİKSEL ANALIZ}

İstatistiksek analiz Statistical Package for Social Sciences (SPSS) Programı ile yapılmıştır.

Çalışma grubundaki sayısal verilerden parametrik olanların ilk önce tanımlayıcı istatistikleri ortalama \pm standart sapma, parametrik olmayanların ortanca (çeyrekler arası aralık (ÇAA)) olarak hesaplanmış, kategorik veriler ise yüzde (\%) olarak verilmiştir. Ardından Ki-Kare testi ile karşılaştırılmalı analizler yapılmıştır. Anlamlılık sınırı $\mathrm{p}<0,05$ olarak kabul edilmiştir.

\section{BULGULAR}

İki y1llık dönemde hastanemiz süt çocuğu servisinde yatarak takip edilen, yaşları 1-24ay arasında olan, Akut Bronşiolit tanılı 759 hastanın dosyaları retrospektif olarak tarand. Bu hastalardan 231'ini $(\% 30,43)$ birden fazla bronşiolit atağ geçiren hastalar oluşturmaktaydi.

Çalışma süresince süt çocuğu servisine Tekrarlayan Bronşiolit tanılı 231 hasta yatırılmıştı.

Hastaların 74'ü $(\% 32,03)$ kiz, 157’si $(\% 67,97)$ erkekti. Hastaların ortanca yaş değeri 9 (ÇAA: 10) ay olup, olguların \%36,8'i ilkbahar, \%33,8'i kış, $\% 16$ 's1 sonbahar, \%13,4'ü yaz mevsiminde hastanemize kabul edilmişti.

Hastalar yaş gruplarına göre gruplandırıldığında; 1-6 ay \%36 (n:83) oranı ile en kalabalı hasta grubunu oluşturmakta iken, 6-12 ay aralığ $\% 33$ (n:76), 12-24 ay aralığ $1 \% 31$ (n:72) oran1 ile en düşük hasta grubunu oluşturmakta idi (Şekil 1).

\section{Hastaların Yaş Grupları (\%)}

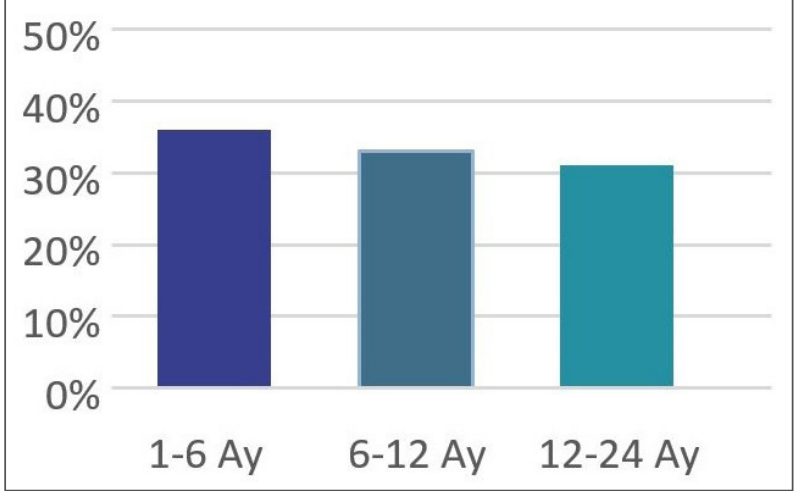

Şekil 1: Hastaların yaş grupları (\%).

Hastaların ilk atak yaş ortalamas 5 ay idi. Olguların 37 hafta ve altında doğum oranı $\% 23,8$ (55) iken 37 haftanın üzerinde doğum oranı \%76,2 (176) idi.

Çalışmaya dahil edilen hastalarda tekrarlayan bronşiolit etyolojisine yönelik olarak yapılan tetkikler sonrası saptanan hastalıklar sirasiyla; en sik wheezing infant (127 hasta, \%55), viral bronşiolit (34 hasta, \%14,7), gastro özefagial reflü (11 hasta, $\% 4,8)$ ve konjenital kalp hastalığı $(8$ hasta, \%3,5) idi. 39 hastada $(\% 16,9)$ ise etyoloji saptanmadi (Tablo 1). Wheezing infant tanılı hastaları, ilk atak yaşı medyan değeri 5 (ÇAA: 5) ay, atak sayısı medyan değeri 4 (ÇAA: 2) idi.

Tablo 1: Tekrarlayan Bronşiolit Tanılı Hastalarda Ayırıcı Tanıda Yer Alan ve Atakların Tekrarlamasına Zemin Hazırlayan Hastalıklar.

\begin{tabular}{|l|l|l|}
\hline \multicolumn{1}{|c|}{ Bulgu } & $\begin{array}{c}\text { Yatan } \\
\text { Hasta } \\
(\mathbf{n})\end{array}$ & $\begin{array}{c}\text { n } \\
\mathbf{( \% )}\end{array}$ \\
\hline WHEEZING İNFANT & 127 & $55,0 \%$ \\
\hline VİRAL BRONŞİOLİT & 34 & $14,7 \%$ \\
\hline GASTRO ÖZEFAGİAL REFLÜ & 11 & $4,8 \%$ \\
\hline KONTENJENITAL KALP HASYALIĞI & 8 & $3,5 \%$ \\
\hline ASTIM & 4 & $1,7 \%$ \\
\hline $\begin{array}{l}\text { SÜT ÇOCUĞU GEÇİCİ HİPOGAMAGLOBU- } \\
\text { LİNEMİSI }\end{array}$ & 3 & $1,3 \%$ \\
\hline İGA EKSİKLİ̆İ & 2 & $0,9 \%$ \\
\hline KİSTIK FİBROZİS & 1 & $0,4 \%$ \\
\hline MIYOKARDİ & 1 & $0,4 \%$ \\
\hline PRIMMER SİLIYER DİSKİNEZI & 1 & $0,4 \%$ \\
\hline ETYOLOJI SAPTANMAYAN & 39 & $16,9 \%$ \\
\hline
\end{tabular}


Olguların \%26,8'inde atopi öyküsü saptanırken, atopi öyküsü olan hastaların \%67,7'sinin ailesinde atopik hastalık olduğu görüldü. Üç ve daha fazla atak geçirenlerin \%29,6 'sında, iki atak geçirenlerin \% 4,2 'sinde atopi öyküsü saptand1. Wheezing infant tanılı hastaların \%31,6'sında atopi öyküsü tespit edildi.

Tekrarlayan bronşiolitli olguların \%14,7'sinde (34 hasta) viral bronşiolit saptanmış olup Solunum Yolu Viral Paneli (SYVP) Sonucuna göre en sik etkenler sirasiyla Respiratuar Sinsityal Virüs (RSV) (10 hasta, \%29,4), Parainfluenza (7 hasta, \%20,6), Rhinovirüs (6 hasta, \%17,6) ve influenza (4 hasta, $\% 11,8$ ) idi (Tablo 2).

Tablo 2: Viral Bronşiolitli Hastaların SYVP Sonuçları.

\begin{tabular}{|l|c|c|}
\hline \multicolumn{1}{|c|}{ SYVP } & $\begin{array}{c}\text { Yatan Hasta } \\
\text { (n) }\end{array}$ & $\mathbf{n}(\%)$ \\
\hline RSV & 10 & $29,4 \%$ \\
\hline PARAINFLUENZA & 7 & $20,6 \%$ \\
\hline RHINOVIRÜS & 6 & $17,6 \%$ \\
\hline INFLUENZA & 4 & $11,8 \%$ \\
\hline ADENOVIRÜS & 3 & $8,8 \%$ \\
\hline BOCAVIRÜS & 2 & $5,9 \%$ \\
\hline HUMAN METAPNÖMO VIRÜS & 2 & $5,9 \%$ \\
\hline
\end{tabular}

Hastanemiz süt çocuğu servisinde yatarak takip edilen Tekrarlayan Bronşiolit tanılı hastaların genel olarak yatış sürelerine bakıldığında ortanca değeri 6 (ÇAA: 4) gün, atak sayısı ortanca değeri ise 3 (CAA: 2) idi. Atak sayısı arttıkça hastanede yatış süresi de artmış olup iki grup arasındaki fark istatistiksel olarak anlamlı idi $(\mathrm{p}<0,001)$. Olguların İlk atak yaşı ortanca değeri 5 (ÇAA: 6) ay idi. İlk atak yaşı düştükçe hastanede yatış süresi artmış ve iki grup arasındaki fark istatistiksel olarak anlamlı idi $(\mathrm{p}<0,001)$.

\section{TARTIŞMA}

Akut bronşiolit, iki yașın altındaki çocuklarda görülen genellikle viral enfeksiyonların neden olduğu, üst solunum yolu enfeksiyonu bulguları (hafif ateş, burun akıntısı, öksürük, burun tıkanıklığg1 gibi) ile başlayıp birkaç gün içinde alt solunum yolu enfeksiyonu bulguları (inflamasyona bağlı hışıltı, havalanma artışı, sibilan ronkus ve/veya krepital raller) ile seyreden akut hastalıktır. Çoğunlukla 2 yaşından daha küçük çocuklarda, en sik 1-6 ay arasinda görülür (3).

Yaşamın ilk yılında hastaneye yatış nedenlerinin \%1'ini akut bronşiolit oluşturmaktadır. Erkek kız oranı 1,5:1dir (8). Küçük solunum yollarında viral enfeksiyonun lokal etkileri yanında birçok anatomik faktör de bronşiolitli bebekte solunum yolunun daralmasına zemin hazırlar. Küçük çocuklarda periferik solunum yollarının darlığı, solunum yollarında sekresyon yapan çok sayıda müköz bez varl1ğ1 ve mukozanın daha gevşek olması onların kolay tıkanmalarına neden olur. Bununla birlikte Kohn delikleri bebek akciğerinde sayıca azdır ve daha az gelişmiştir. $\mathrm{Bu}$ nedenle kollateral ventilasyon erişkinde olduğu kadar etkili değildir. Havalanma fazlalığı ve atelektazi daha kolay gelişir. Çalışmamizda en büyük hasta grubunu 1- 6 ay arası bebeklerin oluşturması (\%36 n:83) anatomik nedenler ve immün sistemin yeterince gelişmemesiyle açıklanabilir. Bununla birlikte akut bronşiolit' in erkek çocuklarında daha sık gözlendiği ve ciddi seyrettiği bildirilmiştir. Erkek çocuklarında, solunum yollarının çapının akciğer hacmine oranının kızlara göre daha küçük olması hastalığın erkek çocuklarda daha çok görülme nedenini açıklayabilmektedir. Benigno ve Ar. 'nın (9) yapmış olduğu bir çalışmada 39 bronşiolitli çocuğun 22 sini erkek, 17 sinin kız olduğu bildirilmiștir. Çalıșmamızın sonuçları daha önce bildirilen sonuçlarla uyumlu olup hastaların \%67,97 (n:157)'si erkekti.

Akut Bronşiolit her mevsim görülebilse de en sık kış mevsiminde ve özellikle Ekim ile Mayıs ayları arasında epidemilere yol açar (10). İstanbul'da yapılan bir çalışmada, akut bronşiolit' li olguların \%88'i kasım-nisan ayları arasında kliniğe bașvurmuştur (11). Çalışmamızda olguların \%36,8'i ilkbahar, \%33,8'i k1ş, \%16's1 sonbahar, \%13,4'ü yaz mevsiminde hastanemize kabul edilmişti. En s1k başvurunun diğer çalışmalarla uyumlu olarak ilkbahar ve kış aylarında olduğu görüldü.

Çeşitli yayınlarda bronşiolit etkenlerinin sıklık yüzdesi değişse de sıklık sırası benzerdir ve ilk iki s1rayı Respiratuar Sinsityal Virüs (RSV) ve Parainfluenza virüs almaktadır (4).

Wennergren ve ark.'lar1 hastaneye yatan 100 akut bronşiolit vakasında RSV sıklığını \%50 olarak saptamışlardır (12). Ülkemizde de Ertem ve ark.'larının çalışmasında RSV sıklığ1 65 akut bronşiolit' li hastada \%29 olarak bulunmuştur. RSV dişında bronşiolit'e parainfluenza tip 1 ve tip 3, rinovirüs, adenovirüs, influenza tip A virüsü gibi ajanlar da neden olur (4). Çalışmamızda Tekrarlayan bronşiolitli olguların \%14,7'sinde (34 hasta) viral bronşiolit saptanmış olup Solunum Yolu Viral Paneli Sonucuna göre en sik etkenlerin sirasıyla Respiratuar Sinsityal Virüs (10 hasta, \%29,4), Parainfluenza (7 hasta, \%20,6), Rhinovirüs (6 hasta, \%17,6) ve influenza (4 hasta, \%11,8) olduğu görüldü (Tablo 2).

Akut bronşiolit bir yaş altı bebeklerde hastaneye yatışların en sık nedenidir (13). Yapılan çalışmalarda akut bronşiolitli hastaların hastanede yatış süreleri, yaș ile ters orantılı olup daha küçük çocuklarda hastanede yatış süresinin daha uzun olduğu tespit edilmiştir. Ayrıca tekrarlayan bronşiolitler de atak sayısı arttıkça hastanede yatış süresinin de arttığ́1 görülmüştür (14). Çalışmamızda Tekrarlayan Bronşiolit tanılı hastaların yatış sürelerine bakıld1ğında ortanca değeri 6 (ÇAA: 4) gün, atak sayısı ortanca değeri ise 3 (ÇAA: 2) idi. Atak sayısı arttıkça hastanede yatış süresi de artmış olup iki grup arasındaki fark istatistiksel olarak anlamlı idi $(\mathrm{p}<0,001)$. Olguların İlk atak yaşı ortanca değeri 5 (ÇAA: 6) ay idi. İlk atak yaşı düştükçe hastanede yatış süresi artmış ve iki grup arasındaki fark istatistiksel olarak anlamlı idi $(\mathrm{p}<0,001)$. Bu duruma küçük bebeklerde solunum yollarının anatomik farklılıkları ve immunitenin gelişmemiş olmasının neden olduğu düşünüldü. 
Süt çocukluğu döneminde alt solunum yolu hastalığının en sık nedeni akut bronşiolitlerdir. Bazı risk faktörleri hastalığın görülmesini kolaylaştırmakta ve atakların tekrarlamasına zemin hazırlamaktadır (10). Gastro özofageal reflü, konjenital kalp hastalıkları, kistik fibrozis gibi hastalıklar tekrarlayan, düzelmeyen, tedaviye yanıtsız, dirençli vakalarda ayırıcı tanıda yer almaktadır $(15,16)$. Akut bronşiolit sonrası tekrarlayan hışıltı atakları görülebilir. Bu ataklar, akut bronşiolit' in immün yanıtı değiştirerek astım ortaya çıkmasını kolaylaştırması ya da zaten astımı var olan çocukların tekrarlayan akut bronşiolit atakları geçirmeleri sonucu ortaya çıkabilir. Çocukta ve ailede atopi öyküsü, gastro özefagial reflü, konjenital kalp hastalığ 1 tekrarlayan hışıltı atakları gelişmesi için risk faktörleridir. Bu tür hastalar astım yönünden de değerlendirilmelidir. Çalışmamızda tekrarlayan bronşiolit etyolojisine yönelik yapılan tetkikler sonrası saptanan hastalıklar sirasiyla en sik wheezing infant (127 hasta, \%55), viral bronşiolit (34 hasta, \%14,7), gastro özefagial reflü $(11$ hasta, $\% 4,8)$ ve konjenital kalp hastalığ $(8$ hasta, \%3,5) idi. 39 hastada $(\% 16,9)$ ise etyoloji saptanmad1 (Tablo1). Wheezing infant tanılı hastalar ilerde astım ortaya çıkma ihtimali nedeniyle çocuk alerji hekimi takibine yönlendirildi.

Yapılan çalıșmalara göre mekanizması iyi bilinmemekle birlikte bronşiolitli olguların bir kısmında reaktif hava yolu hastalığ gelişmekte, atopi öyküsünün olması bu ihtimali arttırmaktadır (17). Çalışmamızda olguların \%26,8'inde atopi öyküsü saptanırken, atopi öyküsü olan hastaların \%67,7'sinin ailesinde atopik hastalık olduğu görüldü. Üç ve daha fazla atak geçirenlerin \%29,6 'sında, iki atak geçirenlerin \%4,2 'sinde atopi öyküsü saptand. Hastada ve ailede atopi öyküsü bulunmasının bronşiolitli olgularda atak sayısını arttırdığı görüldü.

Akut bronşiolit özellikle kış mevsiminde çocuk acile başvuru ve hastaneye yatışların önemli bir bölümünü oluşturmaktadır. Atakların tekrarlamasında yaş, atopi öyküsü, viral enfeksiyonlar ve GÖR, konjenital kalp hastalığ , kistik fibrozis gibi hastalıklar etkili olabilmektedir. Bu etkenler bilinmesiyle tekrarlayan bronşiolit de atak sayısının artması önlenebilir veya erken teşhisle atakların daha hafif geçirilmesi sağlanarak hayat kalitesi arttırılabilir.

\section{KAYNAKLAR}

1. Berger I, Argaman Z, Schwartz SB. Efficacy of corticosteroids in acutebronchiolitis: Short-termandlong-termfollow-up. Pediatr Pulmonol 1998;26:162-6.

2. Edwards G. Acutebronchitis-aetiology, diagnosisandmanagement. BritMed J 1966;1:963.

3. Çiftel M, Şiraneci R, Biçer S. Çocuklarda akut bronşiolit. JOPP Derg 2009;1 (3):115123.

4. Panitch HB, Callahan CW, Schidlow DV.Bronchiolitisin Children. ClinChestMed 1993; 14:715-29.

5. Leung AKC, Klinier JD, Davies HD. Respiratory Syncytial Virüs Bronchiolitis. J Natl Med Assoc 2005; 97:1708-13.
6. Wohl MEB. Bronchiolit. In: Chernick V, Boat TF, eds. Kendig 'sDisorders of theRespiratoryTract in Children, 7th edition, Philadelphia: W.B Saunders, 2006:42332.

7. Rodriguez $R$, Ramilo O. Respiratory syncytial virus: how, why and what to do. J Infect 2014;68 (1):115-8.

8. Polat A, Erol M, Yiğit Ö, Gayret ÖB. Bronşiolitte predispozan faktörler.JAREM 2016;6:40-4.

9. Benigno V, Cusimano RA, Colanino G, Basile A, Varia F, La Grutta S. Is appearance of bronchiolitis affected by environmental and genetic factors? Pediatr MedChir 1991; 13: 155-7.

10. Schroeder A, and Mansbach JM. Recent evidence on the management of the bronchiolitis. CurrOpinPed 2014;26:32833.

11. Hacımustafaoğlu M. RSV enfeksiyonları. Ankem Derg 2006; 20 (ek 29):240-7.

12. Wennergren G, Hansson S, Engström I, et al. Characteristics and prognosis of hospital treated obstructive bronchitis in childrenaged less than two years.Act a Pediat 1992;81:405.

13. Dalt DL, Bressan S, Martinolli F, et al. Treatment of bronchiolitis: state of art. Early Human Development 2013;89 (S1):31-6.

14. Alvarez AE, Marson FA, Bertuzzo CS, Arns CW, Ribeiro $J D$. Epidemiological and genetic charaecteristics associated with the severty of acute viral bronchiolitis by respiratory syncytial virus. J Pediatr 2013;89: 531-43.

15. Ralston SL, Lieberthal AS, Meissner HC, Alverson BK, Baley JE, Gadomski AM, et al. Clinical practice guideline: the diagnosis, management, and prevention of bronchiolitis. Pediatrics. 2014;134 (5):1474-502.

16. Budhiraja S, Verma $R$, Shields MD. The management of acute bronchiolitis in infants. Pediatrics and Child Health 2012; 23:296-299.

17. Ergin H, Dağdeviren E, Polat A, Kılıç İ, Semiz S, Cinbiş M. Akut Bronşiolitli olguların retrospektif Değerlendirilmesi. ADÜ Tip Fakültesi Dergisi 2005;6 (3):29-32. 